\title{
Neutralizing monoclonal antibodies recognize antigenic variants among isolates of infectious hematopoietic necrosis virus
}

\author{
J. R. Winton*, C. K. Arakawa*, C. N. Lannan, J. L. Fryer \\ Department of Microbiology, Oregon State University, Corvallis, Oregon 97331, USA
}

\begin{abstract}
Neutralizing monoclonal antibodies were developed against strains of infectious hematopoietic necrosis virus (IHNV) from steelhead trout Salmo gairdneri in the Deschutes River of Oregon, chinook salmon Oncorhynchus tshawytscha in the Sacramento River of California, and rainbow trout Salmo gairdneri reared in the Hagerman Valley of Idaho, USA. These antibodies were tested for neutralization of 12 IHNV isolates obtained from salmonids in Japan, Alaska, Washington, Oregon, California, and Idaho. The antibodies recognized antigenic variants among the isolates and could be used to separate the viruses into 4 groups. The members of each group tended to be related by geographic area rather than by source host species, virulence, or date of isolation.
\end{abstract}

\section{INTRODUCTION}

Infectious hematopoietic necrosis virus (IHNV) is a rhabdovirus causing epizootics among wild and hatchery-reared salmonid fish. The virus is widespread in stocks of sockeye salmon Oncorhynchus nerka in Alaska, rainbow trout Salmo gairdneri in Oregon and Idaho, and chinook salmon Oncorhynchus tshawytscha in California, USA (Pilcher \& Fryer 1980). The disease caused by the virus was first reported by Rucker et al. (1953) who observed outbreaks among hatcheryreared sockeye salmon fry in Washington State, USA. In 1958, a similar disease occurred in sockeye salmon fry at the Willamette Hatchery, Oregon. A virus, termed Oregon Sockeye Virus (OSV), was isolated from these fish using newly established cell cultures of Pacific salmon (Wingfield et al. 1969).

At about the same time, epizootics among chinook salmon fry in hatcheries of the Sacramento River in California produced an isolate termed Sacramento River Chinook Virus (SRCV). Initial results suggested this virus was similar to OSV (Wingfield \& Chan 1970).

Amend et al. (1969) recovered viruses from infected rainbow trout and sockeye salmon in British Columbia,

\footnotetext{
- Present address: US Fish and Wildlife Service, National Fisheries Research Center, Bldg. 204, Naval Station, Seattle, Washington 98115 , USA
}

Canada. Because the pathology was characterized by extensive necrosis of the blood-forming tissues of the kidney and spleen, the name infectious hematopoietic necrosis virus (IHNV) was proposed for this third virus. Amend \& Chambers (1970) compared OSV, SRCV and IHNV by electron microscopy, cell culture, and pathogenicity. They suggested the viruses were sufficiently similar that the name infectious hematopoietic necrosis virus be applied to all strains.

McCain et al. (1971) compared these strains serologically using polyclonal rabbit antisera. Their results indicated that OSV and IHNV were indistinguishable while SRCV was closely related. MCAllister et al. (1974) and Hill et al. (1975) used polyclonal rabbit antisera to determine that IHNV was serologically different from other fish rhabdoviruses although slight cross reactions were noted. Schultz et al. (1985) developed the first monoclonal antibody against IHNV. Although the antibody had little neutralizing activity, it reacted with IHNV (as determined by enzyme-linked immunosorbent assay) but did not recognize any of the 3 serotypes of viral hemorrhagic septicemia virus tested.

Leong et al. (1981) reported that differences in molecular weight of structural proteins could be used to identify strains of IHNV and Hsu et al. (1986) used this technique to separate 71 isolates of IHNV into 5 electropherotypes. These types generally correlated with the geographic area from which the isolates were obtained. Mulcahy et 
al. (1984) compared 10 isolates of IHNV by plaque size, growth rate, time of appearance of cytopathic effect (CPE), and optimal growth temperature. All isolates were distinguishable by these tests. An isolate from chinook salmon in the Sacramento River, California, proved to be the most different of the strains tested. There was a general correlation between larger plaque size and more northerly geographic location.

The purpose of this study was to develop neutralizing monoclonal antibodjes against selected strains of IHNV to determine if these highly specific reagents could be used to differentiate between antigenic variants of IHNV in a manner similar to that reported by Wiktor \& Kaprowski (1978) with rabies virus. It was also of interest to determine if isolates of IHNV fell into different neutraijization patterns that would correlate with differences in virulence, host range, or geographic distribution.

\section{MATERIALS AND METHODS}

Virus isolates. Twelve isolates of IHNV were used in this study. The host species, location, and year of isolation are given in Table 1. Three isolates were selected for development of neutralizing monoclonal antibodies (MAbs). These were: RB-76 from adult steelhead trout reared in central Oregon, SRCV from adult spring chinook in central California, and 193-110 recovered from infected yearling rainbow trout in southern Idaho. The strains were chosen because they differed in host species serving as source, geographic location, or virulence. Each isolate was dilution-purified before use and assayed for infectivity by end-point dilution. The $50 \%$ tissue culture infectious dose $\left(\mathrm{TCID}_{50}\right)$ was determined by the method of Reed \& Muench (1938).
Antigen preparation. All viruses were grown and assayed using the chinook salmon embryo cell line CHSE-214 (ATCC CRL 1681). Culture fluids were clarified by low speed centrifugation $(20 \mathrm{~min}$, $3400 \times g$ ) and virus was pelleted by centrifugation at $85000 \times g$ for $1 \mathrm{~h}$ in an SW 28 rotor (Beckman Instruments). The pellet was resuspended in a buffer consisting of $0.05 \mathrm{M}$ Tris, $0.1 \mathrm{M} \mathrm{NaCl}$, and $0.001 \mathrm{M}$ EDTA (TNE) and then partially purified by centrifugation into a 3-step discontinuous gradient (20-35-50\% sucrose in TNE). After centrifugation for $60 \mathrm{~min}$ at $115000 \times \mathrm{g}$ in an SW 50.1 rotor, the viral band was collected from the 20 to $35 \%$ interface and concentrated by centrifugation $(60 \mathrm{~min}, 115000 \times \mathrm{g}$ ) using an SW 50.1 rotor (Beckman Instruments). The pellet was resuspended in $0.5 \mathrm{ml}$ Hanks' balanced salt solution (BSS) which resulted in a ca 400 -fold concentration of virus.

Immunization. Different immunization protocols were used to generate the monoclonal antibodies against the 3 strains of IHNV. Balb/c mice (6 to $8 \mathrm{wk}$ old) were used for each fusion. Mice were injected subcutaneously with $0.1 \mathrm{ml}$ of concentrated and purified RB-76 isolate mixed 1:1 with Freund's complete adjuvant. Then, $21 \mathrm{~d}$ later, they were injected intraperitoneally with $0.1 \mathrm{ml}$ of the virus suspended in BSS. Mice immunized against the SRCV and 193-110 isolates were given two $0.1 \mathrm{ml}$ intraperitoneal injections of one or other virus suspended in BSS, $21 \mathrm{~d}$ apart. Serum was collected from all mice and tested for antibody production by microneutralization as described below. Each mouse received a $0.1 \mathrm{ml}$ intraperitoneal injection 3 to $4 \mathrm{~d}$ before the fusion. Mice immunized with the SRCV isolate received an additional intravenous injection of $0.02 \mathrm{ml}$ in the tail vein $3 \mathrm{~d}$ before fusion

Table 1. Isolates of infectious hematopoietic necrosis virus used in this study

\begin{tabular}{|c|c|c|c|}
\hline Isolate & Host & Geographic area & Year \\
\hline SRCV & Oncorhynchus tshawytscha & Sacramento River, California & 1966 \\
\hline Coleman & Oncorhynchus tshawytscha & Sacramento River, California & 1983 \\
\hline $\mathrm{RB}-76$ & Salmo gairdneri & Deschutes River, Oregon & 1976 \\
\hline OSV & Oncorhynchus nerka & Willamette River, Oregon & 1958 \\
\hline Cedar & Oncorhynchus nerka & Cedar River, Washington & 1979 \\
\hline Lewis & Oncorhynchus tshawytscha & Lewis River, Washington & 1973 \\
\hline Russell & Oncorhynchus keta & Russell Creek, Alaska & 1984 \\
\hline Crescent & Oncorhynchus tshawytscha & Crescent Creek, Alaska & 1984 \\
\hline $193-110$ & Salmo gairdneri & Hagerman Valley, Idaho & 1984 \\
\hline $\mathrm{HO}-7$ & Salmo gairdnen & Hagerman Valley, Idaho & 1984 \\
\hline Shizuoka & Salmo gairdneri & Shizuoka Prefecture, Japan & 1982 \\
\hline $\mathrm{HV}-1$ & Oncorhynchus nerka & Hokkaido Prefecture, Japan & 1971 \\
\hline
\end{tabular}


Fusion. Hybridomas were produced by a modification of the methods described by Mishell \& Shiigi (1980) and Lane (1985). Briefly, spleen cells from immunized mice were fused with SP2 myeloma cells in $50 \%$ polyethylene glycol 1500 and $4000(4: 1)$. The cells were resuspended in hypoxanthine, aminopterin, and thymidine selective medium and plated in 96-well culture plates. Selected hybridomas were cloned a minimum of 2 times by limiting dilution on spleen feeder cells then expanded in culture flasks for in vitro production of antibody.

Screening of hybridomas. A microneutralization procedure was used for initial screening of hybridomas for production of neutralizing antibody. Culture fluid $(100 \mu l)$ was harvested from each well containing a hybridoma and transferred to a well of a fresh microplate containing 96 round-bottom wells. One hundred tissue culture infectious doses $\left(\mathrm{TCID}_{50}\right)$ of virus in $100 \mu 1$ MEM-0 (serum-free Eagle's Minimum Essential Medium with Earle's salts) was added to each well and the plate incubated at room temperature with rocking. After $60 \mathrm{~min}$, the contents of each well were inoculated into the corresponding well of a 96-well plate containing monolayer cultures of Epithelioma papulosum cyprini (EPC) cells (Fijan et al. 1983) and $100 \mu \mathrm{M}$ MEM-10 (Minimum Essential Medium with $10 \%$ fetal bovine serum). Cultures were incubated for $14 \mathrm{~d}$ at $18^{\circ} \mathrm{C}$ and examined daily for cytopathic effect.

Isotype determination. Monoclonal antibody class and subclass were determined by enzyme-linked immunosorbent assay (ELISA). Reagents and procedures for the assay were obtained from a commercial source as a mouse monoclonal sub-isotyping kit (Hyclone Laboratories, E-5051-K).

Titration of antibody and determination of $\log _{10}$ neutralization index. Neutralizing antibody titers were determined using a modification of the alpha procedure of Rovozzo \& Burke (1973). Briefly, hybridoma fluids were diluted 1:5 in MEM-O and reacted with equal volumes of virus dilutions prepared in 96-well microplates having round-bottom wells. After $60 \mathrm{~min}$ incubation, titrations were assayed using monolayers of EPC cells. The $\log _{10}$ neutralization index (LNI) was determined as the difference in exponents of the $\log _{10}$ $\mathrm{TCID}_{50}$ titer between the virus dilutions incubated with and without antibody.

Testing of virus isolates. The 3 reference strains used for production of monoclonal antibodies (RB-76, SRCV, and 193-110) and 9 other isolates from Japan, Alaska, Washington, Oregon, Idaho, and California were tested by neutralization. Three selected monoclonal antibodies (one against each of the reference strains) were used and the LNI for each virus-antibody combination was determined. A reaction in which the LNI was equal to or exceeded 1.7 was scored as posi- tive for neutralization. To prevent variation in virus stocks or hybridoma cultures from affecting the results, the entire cross-neutralization assay was performed on one day with the same pool of reagents.

\section{RESULTS}

\section{Screening of hybridomas}

Initial screening of hybridomas for IHNV-neutralizing activity produced few positive cultures. While many of the hybridomas produced antibody with binding activity for IHNV-infected cells or purified virus as detected by ELISA (data not shown), only one neutralizing monoclonal antibody against RB-76 was found among 216 hybridomas screened. Altogether 405 hybridomas were tested to find one with SRCV-neutralizing activity while 18 of the 1449 hybridomas against 193-110 had neutralizing ability. Three hybridomas showing the highest neutralizing activity for the homologous isolate were selected for use in this study, the RB/B 5 clone secreting antibody against the RB-76 strain, the SRCV/A4 producing antibody against SRCV and the 193-110/B4 cells making antibody against the 193-110 strain of the virus.

\section{Isotype determination}

The RB/B 5 and SRCV/A4 MAbs were of the IgM class. The 193-110/B4 MAb was determined to be an IgG2a subclass.

\section{Titration of antibody}

Hybridoma culture fluid containing MAb was diluted 1:5 and reacted against the homologous strain. At this dilution, no toxicity was evident and the neutralization index was sufficient to allow comparison of isolates. The LNI of the antibodies varied between cultures at each passage, but was always sufficient for use. The LNI of the RB/B5 MAb was consistently in the range of 2.7 to 3.5 (average 2.9), while the LNI for the SRCV/A4 MAb was 1.7 to 2.6 (average 2.0). Cultures producing the $193-110 / B 4$ antibody gave $\log _{10}$ neutralization indices ranging from 1.7 to 3.7 (average 2.6).

\section{Testing of virus isolates}

The MAb RB/B5, prepared against the IHNV strain from steelhead trout in Oregon, neutralized 10 of the isolates of IHNV recovered from 4 species of salmonid 
Table 2. Neutralization indices (by logarithm units) for selected isolates of infectious hematopotetic necrosis virus reacted with 3 monoclonal antibodies

\begin{tabular}{|llll|}
\hline \multirow{2}{*}{ Isolate } & \multicolumn{3}{c|}{ Monoclonal antibody } \\
& RB/B5 & SRCV/A4 & 193-110/B4 \\
\hline California & & & \\
SRCV & 2.2 & 2.1 & 0.2 \\
Coleman & 2.5 & 1.0 & 0 \\
Oregon & & & \\
RB-76 & 2.8 & 0 & 1.1 \\
OSV & 2.1 & 0 & 0.4 \\
Washington & & & \\
Cedar & 2.8 & 0.3 & 1.8 \\
Lewis & 2.9 & 0.2 & 2.5 \\
Alaska & & & \\
Russell & 3.0 & 0 & 1.8 \\
Crescent & 2.5 & 0 & 3.0 \\
Idaho & & & \\
193-110 & 3.0 & 0.1 & 1.8 \\
HO-7 & 0 & 0.3 & 0.7 \\
Japan & & & \\
Shizuoka & 0 & 0 & 0 \\
HV-1 & 3.7 & 1.0 & 2.0 \\
\hline
\end{tabular}

fish collected from locations in Japan, Alaska, Washington, Oregon, Idaho, and California (Table 2). The SRCV/A4 MAb prepared against the SRCV strain from chinook salmon at the Nimbus Hatchery in California gave significant neutralization for only the homologous isolate although partial neutralization was observed with the Coleman and HV-1 isolates. The 193-110 MAb developed against an IHNV strain from rainbow trout in Idaho neutralized the homologous virus and 5 other isolates obtained from Pacific salmon in Alaska, Washington, and Japan. Two of the rainbow trout isolates tested were not effectively neutralized by any of the MAbs, but were confirmed to be IHNV by neutralization with polyclonal rabbit antiserum.

\section{DISCUSSION}

The 12 isolates of IHNV used in this study could be placed into 4 groups based upon their recognition by the 3 neutralizing MAbs. None of the isolates was recognized by all the antibodies.

The SRCV strain was the only isolate effectively neutralized by the SRCV/A4 MAb suggesting that this isolate was antigenically the most different of those tested. McCain et al. (1971) reported that although polyclonal antisera reacted with the 3 strains of IHNV tested, SRCV could be differentiated by plaque neutralization. These findings may be explained by our results which show that while the SRCV/A4 MAb recognized a unique epitope on SRCV, the RB/B5 antibody recognized an epitope shared by other isolates of IHNV, indicating there are both common and unique epitopes for neutralization of SRCV

The different nature of SRCV has been suggested by others who found that isolates of IHNV from chinook salmon in California had biochemical (Hsu et al. 1986) or growth (Mulcahy et al. 1984) characteristics that were unlike isolates recovered from other hosts or geographic locations.

A second group of antigenic variants was represented by the RB-76, OSV, and Coleman Hatchery isolates. These had neutralization epitopes that reacted with the RB/B5 MAb but not with the 193-110/B4 antibody, indicating that the 2 MAbs recognize different epitopes not shared by all isolates.

A third group of isolates was neutralized by both the RB/B5 and the 193-110/B4 antibodies. The 2 isolates from Washington, 2 from Alaska and 1 isolate each from Idaho and Japan showed this pattern of reactivity. Isolates forming this group were generally from the northernmost areas of the geographic range of IHNV and were recovered from all 4 species of fish represented in this study therefore suggesting that the $\mathrm{RB}$ / B5 and 193-110/B4 MAbs do not recognize speciesspecific epitopes.

Although the RB/B5 MAb showed broad reactivity, it failed to neutralize isolates ( $\mathrm{HO}-7$ and Shizuoka) from rainbow trout. Indeed, these 2 isolates were not effectively neutralized by any of the 3 MAbs. The isolates of this fourth group were confirmed to be IHNV by neutralization with polyclonal rabbit sera (data not shown), indicating that additional neutralization epitopes exist. Monoclonal antibodies directed against other epitopes will be needed to complete the antigenic analysis of these isolates.

Our results are not directly comparable with those of Hsu et al. (1986) or Mulcahy et al. (1986) because only a few of the same isolates of IHNV were used. However, our results do support the general findings of these workers who reported that relationships among IHNV strains correlated better with geographic location than with host species. Most of the 5 electropherotypes established by Hsu et al. (1986) are based upon differences in the molecular weight of the nucleocapsid protein. The monoclonal antibodies used in this study are directed against epitopes on the glycoprotein as determined by western blot analysis (data not shown).

There appears to be little relationship between virulence for rainbow trout and any of the 4 neutralization groups identified by the MAbs used in this study. Many isolates of IHNV have been recovered from rainbow trout reared in the Hagerman Valley of Idaho and several of these isolates, as represented by $\mathrm{HO}-7$, are of 
high virulence and not reactive with the RB/B5 MAb (N. Wood pers. comm.) while others (193-110) are highly virulent but react strongly. Neutralization-resistant variants of IHNV have been selected by repeated cloning of wild-type virus in the presence of the RB/B5 and 193-110/B4 MAbs. When tested in rainbow trout, some of the variants showed higher virulence than the original isolate while others showed similar or lower virulence (Roberti 1987).

The results from this study have implications for vaccine development because they show that different neutralization epitopes exist among the isolates tested. It will be necessary to compare the results of cross immunization and passive protection studies to determine the extent to which protection of fish is dependent upon neutralizing antibodies against IHNV. If the epitopes identified by these MAbs are important in protection, it may be necessary to develop IHNV vaccines for different geographic areas.

Our data also suggest that different strains of IHNV are, or have been, present at the same location. Infectious hematopoietic necrosis virus was first introduced into Japan in 1971 with a shipment of sockeye salmon eggs from Alaska (Sano 1976). The HV-1 isolate from Hokkaido, where the first outbreak occurred, shows a pattern of reactivity with these MAbs similar to that of the Alaskan isolates. The virus spread rapidly throughout Japan and an isolate from the Shizuoka Hatchery made in 1971 was neutralized by the RB/B5 MAb (data not shown). In contrast, the 1982 Shizuoka Hatchery isolate used in this study was not neutralized by the RB/ B5 MAb. Likewise, 2 different antigenic variants of IHNV exist within stocks of chinook salmon reared at different hatcheries within the Sacramento River system and among rainbow trout reared at hatcheries in the Hagerman Valley of Idaho. Whether these differences represent antigenic drift due to virus evolution, or whether the movement of fish and eggs has resulted in the introduction of new strains of IHNV will not be clear without a detailed analysis of viral genomes.

While the monoclonal antibodies used in this study did not react with all isolates they appeared to be useful diagnostic reagents. Standard methods for the isolation and identification of fish viruses require the use of established fish cell lines and serum neutralization tests (Amos 1985). Rabbit antisera prepared against IHNV often have low neutralization titers and relatively high cytotoxicity. In contrast, hybridoma fluids containing MAbs against IHNV have essentially no toxicity but show adequate neutralization titers. The $\mathrm{RB} / \mathrm{B} 5 \mathrm{MAb}$ showed the widest reactivity and would be the best reagent for confirmation of IHNV isolates. However, because the RB/B 5 and SRCV/A4 antibodies are IgM type, they would be less useful for other serological tests. On the other hand, the 193-110/B4
MA.b and other (non-neutralizing) IgG types developed during this study showed good binding activity for IHNV and would be appropriate reagents for ELISA and fluorescent antibody techniques.

Acknowledgements. The authors thank D. Hursh and $\mathrm{K}$ Roberti for their technical assistance with portions of this project. This research was sponsored by the NOAA Sea Grant Office, US Department of Commerce, under Grant No. NA81AA-D-00086. Oregon State University, Agricultural Experiment Station Technical Paper No. 8384.

\section{LITERATURE CITED}

Amend, D. F., Chambers, V C. (1970). Morphology of certain viruses of salmonid fishes. $I$. in vitro studies of some viruses causing hematopoietic necrosis. J. Fish. Res. Bd Can. 27 : $1285-1293$

Amend, D. F., Yasutake, W T., Mead, R. W (1969). A hematopoietic virus disease of rainbow trout and sockeye salmon. Trans. Am. Fish. Soc. 98: 796-804

Amos, K. H. (1985). Procedures for the detection and identification of certain fish pathogens, 3rd edn. Fish Health Section, American Fisheries Society, Corvallis

Fijan, N., Sulimanovic, D., Bearzotti, M., Muzinic, D., Zwillenberg, L. O., Chilmonczyk, S., Vautherot, J. F., de Kinkelin, P. (1983). Some properties of the Epithelioma papulosum cyprini (EPC) cell line from carp Cyprinus carpio. Ann. Virol. (Inst. Pasteur) 134: 207-220

Hill, B. J., Underwood, B. O., Smale, C. J., Brown, F. (1975). Physicochemical and serological characterization of five rhabdoviruses infecting fish. J. gen. Virol. 27: 369-378

Hsu, Y L., Engelking, H. M., Leong, J. C. (1986). Occurrence of different types of infectious hematopoietic necrosis virus in fish. Appl. environ. Microbiol. 52: 1353-1361

Lane, R. D. (1985). A short-duration polyethylene glycol fusion technique for increasing production of monoclonal antibody-secreting hybridomas. J. immunol. Methods 81: 223-228

Leong, J. C., Hsu, Y. L., Engleking, H. M., Mulcahy, D. (1981). Strains of infectious hematopoietic necrosis (IHN) virus may be identified by structural protein differences. Develop. biol. Stand. 49: 43-55

McAllister, P. E., Fryer, J. L., Pilcher, K. S. (1974). An antigenic comparison between infectious hematopoietic necrosis virus (OSV strain) and the virus of hemorrhagic septicemia of rainbow trout (Salmo gairdneri) (Denmark strain) by cross neutralization. J. Wildl. Dis. 10: 101-103

McCain, B. B., Fryer, J. L., Pilcher, K. S. (1971). Antigenic relationships in a group of three viruses of salmonid fish by cross neutralization. Proc. Soc. exp. Biol. Med. 137: 1042-1046

Mishell, B. B., Shiigi, S. M. (1980). Selected methods in cellular immunology. W. H. Freeman and Co., San Francisco

Mulcahy, D., Pascho, R., Jenes, C. K. (1984). Comparison of in vitro growth characteristics of ten isolates of infectious hematopoietic necrosis virus. J. gen. Virol. 64: 2199-2207

Pilcher, K. S., Fryer, J. L. (1980). The viral diseases of fish: a review through 1978. CRC Crit. Rev, Microbiol. 7: 287-364

Reed, L. J., Muench, H. (1938). A simple method of estimating fifty per cent endpoints. Am. J. Hygiene 27: 493-497

Roberti, K. A. (1987). Variants of infectious hematopoietic necrosis virus selected with glycoprotein-specific monoclonal antibodies. Master's thesis, Oregon State Univ. Corvallis 
Rovozzo, G. C., Burke, C. N. (1973). A manual of basic virological techniques. Prentice-Hall, Englewood Cliffs

Rucker, R. R., Whipple, W. J., Parvin, J. R., Evans, C. A. (1953). A contagious disease of salmon possibly of virus origin. U.S. Fish. Wildl. Ser. Fish Bull. 76: 35-46

Sano, T. (1976). Viral diseases of cultured fishes in Japan. Fish Pathol. 10: 221-226

Schultz C. L., Lidgerding, B. C., McAllister, P. E., Hetrick, F. M. (1985). Production and characterization of monoclonal antibody against infectious hematopoietic necrosis virus. Fish Pathol. 20: 339-341

Wiktor, T. J., Koprowski, H. (1978). Monoclonal antibodies against rabies virus produced by somatic cell hybridization: detection of antigenic variants. Proc. natn. Acad. Sci. U.S.A. 75: 3938-3942

Wingfield, W. H., Chan, L. D. (1970). Studies on the Sacramento River chinook disease and its causative agent. In: Snieszko, S. F. (ed.) A Symposium of Diseases of Fishes and Shellfishes. Special Publication No. 5. American Fisheries Society, Washington D. C., p. 307-318

Wingfield, W. H., Fryer, J. L., Pilcher, K. S. (1969). Properties of the sockeye salmon virus (Oregon strain). Proc. Soc. exp. Biol. Med, 130: 1055-1059 